Mineralogy and Petrology (2007) 89: 283

DOI 10.1007/s00710-006-0172-2

Printed in The Netherlands

Mineralogy and Petrology

\title{
Erratum
}

\section{Application of rutile thermometry to eclogites}

\section{T. Zack and G. L. Luvizotto}

Published online February 13, 2007; (C) Springer-Verlag 2007

In the article "Application of rutile thermometry to eclogites" by T. Zack and G. L. Luvizottow [Mineralogy and Petrology (2006) 88: 69-85; DOI 10.1007/s00710-006-0145-5], the author's name G. L. Luvizottow is misspelled. It should read Luvizotto.

Verleger: Springer-Verlag GmbH, Sachsenplatz 4-6, 1201 Wien, Austria - Herausgeber: Prof. Dr. J. G. Raith, Department Angewandte Geowissenschaften und Geophysik, Lehrstuhl für Mineralogie und Petrologie, Peter-Tunner-Straße 5, 8700 Leoben, Austria - Redaktion: Peter-Tunner-Straße 5, 8700 Leoben, Austria - Hersteller: Satz und Umbruch: Thomson Press (India) Ltd., Chennai; Offsetdruck: Krips bv, Kaapweg 6, 7944 HV Meppel, The Netherlands - Verlagsort: Wien - Herstellungsort: Meppel - Printed in The Netherlands. 